\title{
Health Promotion Media Exposure and Student Compliance Toward Smoke-Free School Regulation In Sleman Yogyakarta
}

\author{
Heni Trisnowati ${ }^{1}$, Rini Dwi Susanti ${ }^{2}$, Nuraini ${ }^{3}$ \\ 1,2,3Study Program of Public Health, Faculty of Health Sciences, Universitas Respati \\ Yogyakarta (UNRIYO), Yogyakarta, Indonesia
}

\begin{abstract}
The number of adolescent smokers in Indonesia are increasing with the highest prevalence on age 15-19. Implementation of smoke-free schools (SFS) aims to reduce adolescent smokers and protect school residents from cigarette smoke exposure. Public Senior High School 1 Cangkringan, Sleman has declared a SFS since 2019 by providing health promotion media such as posters and stickers in the school area. This study describes the implementation of SFS and to determine the relationship between health promotion media exposure and student compliance toward SFS regulations using quantitative methods with a crosssectional design. Data collection was carried out through observation with checklists and online surveys with a google form. Sampling using accidental sampling method to 155 respondents and data analysis using SPSS version 17 with Chi-Square test. All respondents stated that the implementation of SFS is good and the results of observations showed that the input, process, and output indicators of SFS implementation had been fulfilled. There was a relationship between exposure to health promotion media in the form of posters with student compliance with SFS regulations $\rho$ value $\leq \alpha(0.004 \leq 0.05)$. In conclusion, the high exposure to health promotion media has implications for the high compliance of students to SFS regulations.
\end{abstract}

\begin{abstract}
ABSTRAK
Jumlah perokok remaja di Indonesia terus mengalami peningkatan, dan prevalensi tertinggi usia 15-19 tahun. Penerapan Kawasan Tanpa Rokok (KTR) di sekolah bertujuan untuk menurunkan jumlah perokok remaja dan melindungi warga sekolah dari paparan asap rokok. SMAN 1 Cangkringan, Sleman telah mendeklarasi sebagai sekolah dengan KTR sejak tahun 2019. Penelitian ini mendeskripsikan implementasi KTR di sekolah dan untuk mengetahui hubungan paparan media promosi kesehatan dengan kepatuhan siswa terhadap peraturan KTR. Menggunakan metode kuantitatif dengan rancangan cross sectional. Pengumpulan data dilakukan melalui observasi dengan cek list dan survei online dengan google form. Pengambilan sampel dengan metode sampling aksidental sebanyak 155 responden. Seluruh responden menyatakan bahwa implementasi KTR di sekolah dalam kategori baik dan hasil observasi menunjukkan indikator input, proses dan output pelaksanan KTR disekolah sudah terpenuhi. Terdapat hubungan antara paparan media promosi kesehatan dengan kepatuhan siswa terhadap peraturan KTR di sekolah dengan nilai $\rho \leq \alpha \quad(0,004 \leq 0,05)$ Kesimpulannya, tingginya paparan media promosi kesehatan berimplikasi pada tingginya kepatuhan siswa terhadap peraturan KTR di sekolah.
\end{abstract}

KEYWORDS

Smoke-Free School, health promotion media, compliance, students

KATA KUNCI Kawasan Tanpa Rokok; media promosi kesehatan; kepatuhan siswa 


\section{INTRODUCTION}

Cigarettes have become an inseparable part of human life. Cigarettes symbolize masculinity, courage, strength, courage, and toughness. Smoking can harm health because cigarettes contain dangerous substances that are addictive, namely nicotine (Sukmana, 2009) Smoking-induced disease is a health problem in the world (Kemenkes RI, 2011). Every ten adult deaths, one person dies from cigarette smoke. The latest data from WHO states that smoking causes 5 million cases annually, and $70 \%$ occur in developing countries, including Indonesia. If there is no effort to control tobacco, the number of world smokers will continue to increase. WHO estimates that in 2025 there will be 10 million deaths per year (Kemenkes RI, 2011). Smoking is a very harmful activity, both active and passive smokers. Every cigarette smoke generated from cigarettes contains harmful substances: the more people smoke, the more danger there is. The cigarette pack clearly states that cigarettes can kill you. However, it seems that the warning is not taken seriously for active smokers (Setiawan et al., 2017).

Efforts to control the impact of cigarette consumption on health in Indonesia have the strength in the form of Law Number 36 of 2009 concerning Health, Government Regulation Number 109 of 2012 concerning Safeguarding of Materials Containing Addictive Substances in Tobacco Products for Health, and Regulation of the Minister of Health Number 28 of 2013 concerning Inclusion of Health Warnings and Health Information on Tobacco Product Packaging. Also, the policies in providing funds for tobacco control are mandated in Law Number 39 of 2007 concerning Excise and cigarette tax regulations as stipulated in Law Number 28 of 2009 concerning Regional Taxes and Regional Retributions (Kemenkes RI, 2013). Smoking restricted areas are the legal basis for every person or entity to obtain the same rights for a healthy smoke-free area, and every person or entity carries out the obligation to maintain and implement regulations that have been made to preserve the environment (Permekes RI, 2017)

The rise of advertisements in broadcasting and outdoor media and sponsorship by the tobacco industry has initiated children and adolescents to smoke early (Trisnowati et al., 2015). Since 2013, smoking prevalence among adolescents aged 10-18 years has increased, from 7.2\% to $9.1 \%$ (Indonesian Ministry of Health, 2018). Besides, there is an increase in smoking in adolescents and productivity, especially in the 15-19 age group (Badan Penelitian dan Pengembangan Kesehatan, 2014).

Schools are teaching and learning facilities that should have a clean, comfortable and healthy environment. The existence of cigarettes or cigarette smoke in schools will interfere with the health of every student and all school residents. Nowadays, it is often found that many students or students smoke, especially students at the high school level. Students and sometimes other school residents usually smoke in the school environment (Setiawan et al., 2017). 
Smoke Free-School (SFS) regulation, An area that is declared prohibited from carrying out smoking activities or activities to produce, sell, advertise and/or promote tobacco products. In this case, the government issued a Joint Regulation of the Minister of Health and Minister of Home Affairs No. 188 / Menkes / PB / I / 2011 No. 7 of 2011 concerning Guidelines for SFS (Kemenkes, 2011). The Regent of Sleman stipulates a Regional Regulation on No Smoking Areas (Perbub Sleman, 2012). SFS application in the Sleman area was implemented from 2005 to 2017. There was an increase in smokers by 17 percent in the 10 to 14 year age range, with the highest smokers coming from the 15-19 age group (Kemenkes RI, 2018). SMAN 1 Cangkringan declared a Smoke Free-School (SFS) on September 13, 2019. Besides, this school is designated as an educational institution that cares for a healthy, clean and beautiful environment. Schools already have regulations on smoking prohibition. Even in every corner of the school, there are posters and stickers regarding smoking-free areas (Media Cetak Sembada Kabupaten Sleman, 2019).

The observations in the school environment found billboards for areas without smoking, smoking prohibition signs, and several posters in school corners such as in the canteen and front of the classrooms. Also, school residents are prohibited from carrying cigarettes and smoking in the school area. The observations also show no smell of cigarettes at the research location, and no cigarette sticks were found. When conducting interviews with several students, they mentioned that they had never seen other students smoking in the school environment. When asking the counseling teacher, he said that a grade 10 student had smoked at school because they did not understand the SFS regulations in the school area, but when the counseling teacher warned, the student never repeated his mistake. The seller in the canteen also stated that he had never provided or sold cigarettes.

From the above description, SMAN 1 Cangkringan has implemented the SFS regulation. The purpose of this study was to determine the relationship between health promotion media exposure and student compliance with SFS regulations at SMAN 1 Cangkringan, Sleman Yogyakarta.

\section{METHOD}

This study uses a quantitative method with a cross-sectional design to study the correlation between risk factors by collecting data at a particular time (Ariani, 2014). The researcher made the questionnaire using the SFS implementation guideline theory (Kemenkes RI, 2011). Data collection was carried out through observation with checklists and online surveys with a google form. Data analysis used SPSS software 
which was carried out univariately with frequency distribution and bivariate using the chi-square statistical test

The population in this study were all students of class XI and XII of SMAN 1 Cangkringan, totaling 253 students. The sample was calculated using the Yamane formula because the population size was known (Sugiyono, 2018), so that the total sample size was 155 people. Respondent data consisted of age, gender, and smoking status. Age uses a ratio scale, while the implementation of SFS regulations is measured through input, process, and output indicators as stated in the SFS implementation guidelines (Kemenkes, 2011).

Exposure to health promotion media about SFS researched are in posters, pamphlets, billboards, and others whose contents can stimulate students to read and understand SFS regulations. This variable uses an ordinal scale by providing four answer choices. Option 1 = Never seen health promotion media in the last one month; $2=$ rarely seen health promotion media over the previous 1 month; 3 = Sometimes looking at health promotion media over the last 1 month; $4=$ Often see health promotion media over the last 1 month. Moreover, Student compliance with the SFS regulations is defined as student compliance with the SFS regulations implemented in school, including not carrying cigarettes and not smoking in the school environment. This variable uses a nominal scale (H Trisnowati et al., 2015).

\section{RESULT AND DISCUSSION}

Female respondents are more than male respondents (67\%: 32.3\%). The average age of the respondents was 15-19 years. Only a small proportion of respondents smoke (2.6\%). All respondents stated that implementing the SFS regulations at SMA N 1 Cangkringan was good. There are more female respondents than male respondents because the data collection technique uses accidental techniques, and the majority of those who fill out the questionnaire are female students. This is reinforced by school data which shows the number of female students is more than male students with the following data: 393 students, 240 are female, while 153 are male (SMAN 1 Cangkringan, 2020).

The analysis results show a significant relationship between exposure to health promotion media and student compliance with SFS regulations at SMA N 1 Cangkringan. 
Tabel.1

Health Promotion Media Exposure and Student Compliance toward SFS Regulations in Sleman Yogyakarta $(\mathrm{N}=155)$

\begin{tabular}{|c|c|c|c|c|c|c|c|c|}
\hline & & \multicolumn{4}{|c|}{$\begin{array}{c}\text { Students'Students' } \\
\text { compliance }\end{array}$} & \multirow[t]{3}{*}{ Total } & \multirow{3}{*}{$\%$} & \multirow{3}{*}{$\begin{array}{l}\text { Asymp. } \\
\text { Sig. (2- } \\
\text { sided) }\end{array}$} \\
\hline & & \multicolumn{2}{|c|}{ disobedient } & \multicolumn{2}{|c|}{ obedient } & & & \\
\hline & & $\mathrm{N}$ & $\%$ & $\mathrm{~N}$ & $\%$ & & & \\
\hline \multirow{2}{*}{$\begin{array}{c}\text { Media } \\
\text { exposure }\end{array}$} & Tinggi & 0 & 0 & 129 & 83,2 & 129 & 83,2 & \multirow[t]{2}{*}{0,004} \\
\hline & Rendah & 3 & 1,9 & 23 & 14,8 & 26 & 16,8 & \\
\hline Total & & 3 & 1,9 & 152 & 98,1 & 155 & 100 & \\
\hline
\end{tabular}

The results showed that all students (respondents) stated that implementing SMA N 1 Cangkringan was good. This exemplary is also proven by direct observation at the research site, namely by looking at the input, process, and output of the SFS regulations. The results of the input at SMA N 1 Cangkringan were the existence of a policy on SFS (prohibited from carrying cigarettes in the school environment and no smoking in schools), the presence of personnel assigned to monitor SFS in the teaching and learning process, and the existence of promotional media on smoking bans such as posters, billboards, and no smoking signs). The process of implementing the SFS regulations at SMA N 1 Cangkringan has also been very good in the arrangement of duties and responsibilities in implementing the SFS such as installing SFS signs in every corner of the school (the entrance and in front of the class). Also, the SFS policy announcement has been installed (posters, smoking prohibition signs, and wallpaper). The output, there are no smell of cigarette smoke and smokers were not smoking in the school environment because there are sanctions for students who violate the SFS regulations by providing score that will impact their final semester report.

The application of SFS can be seen from the delivery of SFS messages to patients or visitors through posters, smoking prohibition signs, announcements, loudspeakers, and others. There is also the provision of asking questions, and there is SFS supervision (Kemenkes RI 2011). In this case, the implementation of the SFS regulation at the research location has been perfect because it has met the criteria as an SFS school.

The results of this study are in line with previous research conducted in the Yogyakarta city school environment that in general, the compliance of schools in the city of Yogyakarta with the SFS regulation tends to be high, with the result of process indicators that $80 \%$ of schools have received SFS policy socialization directly from the health center, lecturers or students who conduct research. However, on the other hand, of the 162 schools, $43.5 \%$ of the schools had no task or responsibility arrangements in implementing SFS. The output indicator shows that more than $90 \%$ of schools in Yogyakarta are smoke-free. Almost all schools (98.1\%) of school residents warned if 
people smoked in the school environment, but $17.9 \%$ of school members still smoked (Trisnowati \& Marlinawati, 2020).

The results showed that exposure to health promotion media at SMA N 1 Cangkringan was high, almost all respondents saw and read health promotion media exposure well. In SMA N 1 Cangkringan, this happened because many presented health promotion media about smoking prohibition such in posters, billboards, and smoking prohibition signs. The promotional media can also be found in school areas such as the school canteen, in front of the entrance, in front of the class, and front of the library. Based on this research, the SFS regulations are displayed using posters, billboards, and nonsmoking signs located in school areas such as canteens and the front of classroomsm hoping that students can more easily find or see health promotion media to encourage compliance with SFS regulations in schools.

The study results on the compliance variable showed that almost all respondents in SMA N 1 Cangkringan obeyed the SFS regulations. However, some students still violated the SFS regulations (1.9\% of 155 respondents). Some students still violate the SFS regulations because there are still several shops selling cigarettes outside Cangkringan 1 High School, such as beside and in front of the school environment. From the respondent's statements, some students still bring cigarettes to school, even though these students do not smoke at school, this violates one of the SFS regulations at SMA N 1 Cangkringan. The criteria for "obeying" in this study were when students obeyed the SFS regulations, namely not smoking in school and not carrying cigarettes to school. If the student violated any of these rules, the student was said to be "disobedient" to the SFS regulations.

Based on the analysis that has been done using the Chi-Square test analysis, the results are $\rho$ value of 0.004 and $\alpha 0.05$. This result shows a significant relationship between exposure to health promotion media and student compliance with SFS regulations because $\rho$ value $\leq \alpha$. Thus, if the use of health promotion media is continuously increased, it will be able to assist in implementing the SFS regulations in schools. The results of this study are supported by research by Dewi et al. with a study entitled "Analysis of Factors Affecting Employee Compliance with the No Smoking Area Policy at the Palembang Civil Service Police Unit Office" with the ineffective regional regulations, this is evidenced by low employee compliance with policies smoking area is $30.4 \%$, there is an influence between knowledge of local regulations $(p=0,000)$, knowledge of the dangers of smoking $(p=0,000)$, smoking prohibition sign $(p=0,000)$, application of sanctions $(p=0,000)$, support superiors $(p=0,000)$, regarding employee frustration with the no-smoking area policy. One of the factors in this study, namely the sign that the smoking ban is a health promotion medium about SFS (Dewi et al., 2018).

The results of this study are also in line with the research of Annashr, et al. Entitled "The Effectiveness of Audiovisual-Based Health Promotion in Increasing Compliance with 
Filariasis Medication in Kuningan District." This research shows a significant difference between the proportion of adherence to taking medication among respondents before and after being given health promotion with the audiovisual method. Besides, this study also compares lecture-based health promotion methods. However, this method shows a significant difference in the proportion of medication adherence among respondents before and after being given health promotion using the lecture method. That way, health promotion using audiovisual media has higher effectiveness in increasing community compliance to take filariasis preventive drugs (Annashr \& Amalia, 2018).

The results of this study are in line with research conducted at SMAN 1 Sigli Aceh; there is an influence between information on the compliance of Class $X$ students with the smoking ban with a p-value of 0.033 . This study suggests that there should be more positive group activities that can divert teenagers from smoking behavior, for example, by holding sports and religious extracurricular activities. In addition, it further improves the counseling guidance section so teenagers can be more disciplined in socializing and choosing friends (Wahyuni \& Nur Asiah, 2020).

The results of this study are reinforced by the results of research on students of SMA Kader Pembangunan in Baturaja Palembang, which shows that there is a significant relationship between knowledge of non-smoking areas regulations and non-smoking area compliance. The implementation of the no-smoking area policy is still lacking, so the effectiveness of the no-smoking area in reducing active smokers has not shown a significant number, but there is a tendency to decrease smokers. The results showed that students who supported the implementation of the No-Smoking Area were good enough, namely, 49.0\%. In contrast, many students at the Kader Pembangunan High School did not comply with the no-smoking area, and this was due to the influence of friends or the environment where the students were (Harto, 2018).

Furthermore, the study results are also relevant to the research results conducted at State High Schools in Bogor City, the application of KTR in the good category because the recapitulation of all dimensions obtained a final score of 3.50. Meanwhile, the effectiveness of the Policy Evaluation of Bogor City Regional Regulation No. 12 of 2009 concerning Non-Smoking Areas got a score of 3.86, which according to interpretation, is in a suitable category. This is because the understanding of this regulation has been well understood, and this policy has been considered successful (Setiawan et al., 2017).

The results of this study differ from the results of research conducted at senior high schools and the equivalent in Madiun, East Java. The implementation of KTR showed a relationship between the implementation of non-smoking areas with the availability of funding sources with a p-value of 0.004 and infrastructure support with a p-value of 0.001. Furthermore, the study results show no relationship between the implementation of a No Smoking Area and the availability of human resources and policy support. The implication of the data illustrates that the implementation of KTR 
has not been maximized because there were still students, teachers, and employees who smoked in the school environment. The KTR policy was available and complete with punishment, but the commitment to implement and punish was not explicitly shown. This condition occurs in students, teachers, and employees who violate the KTR policy in the school environment (Marchel et al., 2019).

Compliance is a form of social influence in which individual activities or actions respond to direct orders from other individuals who act as authorities (McLeod, 2007). Compliance will be realized when someone is ordered to do something by the authority holder who is where the person is. Changes in a person's attitude and behavior in carrying out other people's orders will be involved when someone becomes obedient to orders (Wati \& Qomaruddin, 2020). The results showed that $51.6 \%$ had sufficient compliance with the No Smoking Area (KTR) regulations in UPTD Kampung Anak Negeri, Surabaya, supported by strict rules and sanctions related to cigarettes or smoking from UPTD Kampung Anak Negeri to foster children. Tough sanctions are one way to make foster children feel deterred from repeating rule violations (Wati \& Qomaruddin, 2020).

Although this research has been carried out optimally, it cannot be separated from its limitations. Due to the Covid 19 pandemic, there has been a change in the data collection method from offline to online using the google form. Data collection was assisted by a facilitator, a counseling guidance teacher. This facilitator provides a link to the class group, and then the researcher receives the results of filling out the online questionnaire from each respondent. Changes in the way this data was collected may have influenced the research results. Researchers cannot directly supervise the course of the research so that respondents may fill out the questionnaire not following their actual condition.

\section{CONCLUSION}

The types of health promotion media at SMA N 1 Cangkringan are posters, billboards, and smoking prohibition signs. All respondents stated that implementing the SFS regulations at SMA N 1 Cangkringan was good. Almost all respondents at the school were exposed to high health promotion media. Nearly all respondents at SMA N 1 Cangkringan comply with the SFS regulations. There is a significant relationship between health promotion media and student compliance with SFS regulations at SMA $\mathrm{N} 1$ Cangkringan with 0.004 . This conclusion implies that using health promotion media can assist in implementing the SFS regulations.

Based on the results of this study, it is suggested that SMA N 1 Cangkringan use these findings to discipline student behavior in schools by using health promotion media. Health promotion media can also be made as attractive as possible so that students can be more interested in reading them and easier to understand. Furthermore, students 
are expected not to violate any rules implemented in schools, including smoking prohibition regulations in schools because all regulations are made to form a good attitude. For further researchers, they can carry out similar research, which can develop research more slightly, for example, health promotion media and seen from the types of posters, pamphlets, leaflets, tv, etc. With that, we will know more about which types of health promotion media are more effective in helping students comply with the existing SFS regulations in schools.

\section{REFERENCES}

Annashr, N. N., \& Amalia, I. S. (2018). Efektivitas promosi kesehatan berbasis audiovisual filariasis di Kabupaten Kuningan. jurnal Ilmu Kesehatan Bhakti Husada:

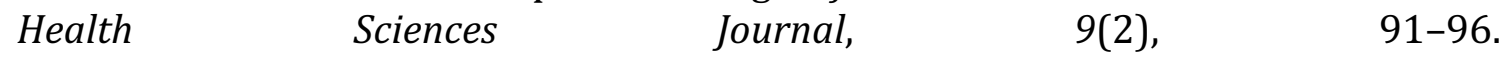
https://ejournal.stikku.ac.id/index.php/stikku/article/view/66

Ariani, A. P. (2014). Aplikasi Metode Penelitian Kebidanan dan Kesehatan Reproduksi. Nuha Medika.

Badan Penelitian dan Pengembangan Kesehatan, T. C. S. C. (2014). Bunga rampai fakta tembakau dan permasalahannya di Indonesia.

Dewi, Y. K., K, F. N., \& Lionardo, A. (2018). Analisis Faktor-Faktor yang Mempengaruhi Kepatuhan Pegawai terhadap Kebijakan Kawasan Tanpa Rokok di Kantor Satuan Polisi Pamong Praja Kota Palembang. Sriwijaya Journal of Medicine, 1(1), 8-15.

Harto, T. (2018). Hubungan Antara Pengetahuan Peraturan Kawasan Tanpa Rokok Terhadap Kepatuhan Kawasan Tanpa Rokok Pada Siswa SMA di Baturaja Tahun 2007. JKAB: Jurnal Kesehatan Abdurrahman, 7(1), 12-19. http://www.ejournal.stikesabdurahman.ac.id/index.php/jkab/article/view/72

Kemendikbud. (2016). Kamus Besar Bahasa Indonesia. Jakarta, 2016. https://kbbi.kemdikbud.go.id/

Kemenkes RI. (2011). Pedoman Pengembangan Kawasan Tanpa Rokok. Kementerian Kesehatan Republik Indonesia.

Kemenkes RI. (2013). Peraturan Pemerintah No 40 Pelaksanaan Undang-Undang Nomor 35 Tentang Narkotika.

Kemenkes RI. (2018). Laporan Riskesdas 2018. In Kementerian Kesehatan RI. Badan Penelitian dan Pengembangan Kesehatan (Balitbangkes).

Marchel, Y. A., Indraswari, R., \& Handayan, N. (2019). Implementasi Kawasan Tanpa Rokok Sebagai Pencegahan Merokok Pada Remaja Awal. Jurnal PROMKES, 7(2), 144. https://doi.org/10.20473/jpk.v7.i2.2019.144-155

Media Cetak Sembada Kabupaten Sleman. (2019). SMAN 1 Cangkringan Deklarasikan Diri sebagai Kawasan Tanpa Rokok. https://mediacetar.slemankab.go.id/sman-1cangkringan-deklarasikan-diri-sebagai-kawasan-tanpa-rokok/.

Perbub Sleman. (2012). Peraturan Bupati Sleman No 42 Tahun 2012 Tentang Kawasan Tanpa Rokok. In Sekretaris Daerah Kabupaten Sleman.

Permekes RI. (2017). Peraturan Menteri Kesehatan RI Nomor 56 Tahun 2017. In 
Kemenkes RI.

Setiawan, N. P., Hernawan, D., \& Salbiah, E. (2017). Evaluasi Kebijakan Peraturan Daerah Kota Bogor No 12 Tahun 2009 Tentang Kawasan Tanpa Rokok (Studi Kasus Pelaksanaan Kawasan Tanpa Rokok Pada Sekolah Menengah Atas Negeri Di Kota Bogor). Jurnal Governansi, 3(1), 13. https://doi.org/10.30997/jgs.v3i1.809

SMAN 1 Cangkringan. (2020). Profil SMAN 1 Cangkringan. https://sman1cangkringan.sch.id/

Sugiyono. (2018). Metode Penelitian Kuantitatif. Alfabeta.

Sukmana, T. (2009). Mengenal Rokok dan Bahayanya. Jakarta: Be Hampion, 2009. Be Hampion.

Trisnowati, H, Prabandari, Y. S., \& Padmawati, R. S. (2015). Paparan Iklan Rokok Dan Perilaku Merokok Pada Remaja Smp Di Kabupaten Bantul, Daerah Istimewa Yogyakarta. Jurnal Medika Respati, Vol X No 3.

Trisnowati, Heni, \& Marlinawati, V. U. (2020). Monitoring Kepatuhan Peraturan Kawasan Tanpa Rokok di Lingkungan Sekolah Kota Yogyakarta. Disease Prevention and Healt Publich Jurna, 14(1). http://journal2.uad.ac.id/index.php/dpphj/article/view/1802/pdf

Wahyuni, S., \& Nur Asiah, D. (2020). Faktor Yang Berhubungan Dengan Kepatuhan Siswa Terhadap Larangan Merokok Di Sman 1 Sigli Provinsi Aceh Tahun 2019. Majalah Kesehatan Masyarakat Aceh (MaKMA), 3(1), 112-118.

Wati, M. D. M., \& Qomaruddin, M. B. (2020). Analysis of Compliance with Non-Smoking Area Regulations in Foster Care of Regional Technical Implementation Unit of $\begin{array}{llll}\text { Kampung Anak Negeri. Jurnal PROMKES, } & 99 .\end{array}$ https://doi.org/10.20473/jpk.v8.i1.2020.99-110 